\title{
RAWLS IN THE AFRICAN PREDICAMENT: SOME THEORETICAL CONSIDERATIONS
}

\author{
Adeshina Afolayan, PhD, Department of Philosophy, Uni- \\ versity of Ibadan, Nigeria \\ Email: shina731999@yahoo.com
}

\begin{abstract}
The colonial experience in Africa is an epochal phenomenon. This is because the postcolonial conditions became crippling enough to determine the direction that Africa would take. The colonial logic through series of sociocultural, economic and political "pre-texts" ensured the disruption of the African psyche and societies. One of the ways in which the Africa is coming to term with its disrupted existence is the attempt to recreate a democratic community on demotic principles. The people are essential because they were crucial to the decolonisation process. However, because the colonial structures remained largely uninterrogated by the nationalists, the African state lost its legitimacy and the disenchanted Africans discovered meaningfulness in their ethnic enclaves. How then can African achieve a liberating democratic community? How does liberal democracy, and its arch-advocate Rawls, feature in this attempt at legitimating the postcolonial African state? How meaningful is the idea of an African liberal democracy?
\end{abstract}

In Africa, there is a wealth of traditional general ideas, which make themselves felt both in the present-day theories of politics and society in that continent, and also, to the extent of independent countries at least, in their practices. It is important to carry out investigations into the theories of 
these cultures, and indeed it is such investigations which would reveal what portions of the West and the East, or indeed any foreign cultures, are likely to survive in Africa, and the pattern of the modifications which they are likely to suffer.

--William Abraham ${ }^{1}$

Benjamin Disraeli is said to have once remarked, ñDamn your principles; stick to your party.ò African leaders, in sticking to their parties, and not to binding principles, may yet find that, in the end, what they call country is not really country anymore, but an empty space devoid of normative meaning.

\section{ð Ifeanyi Menkiti}

\section{Introduction: Background and Motif}

It has become trite for African scholars to lament the predicaments that have faced the continent as what someone called the ñIsland of Want.ò What is not so prevalent is a ready-made solution to the African crisis. In fact, extant ñsolutionsò to the crisis are crumbling in the face of intractable realities. The atmosphere of despair and uncertainty that pervades the postcolonial, post-independent Africa is so pessimistic that one is likely to throw up his hands in abject submission to the predicament. This essay is just one more attempt at confronting the African crisis. Precisely, it attempts to critically confront a plausible panacea to the postcolonial legitimation crisis that has been the lot of most African states since independence.

There is a strategic relationship between the postcolonial ethnic resurgence that represents the core of the African predicament and the problem of democratic govern- 
ance and legitimacy. The confluence is this: The people who featured as the significant factor in the nationalistic struggle against colonialism suddenly discovered that the revered nationalists who were the symbols of their social hope could not ñdeliver the goods. Ò In other words, the social question that motivated the nationalistic struggle lost its critical edge in its transmutation into the national question in the attempt of the nationalists to understand the administrative structures left by the colonialists. It therefore became a decisive is sue that for the emergent leadership to acquire the legitimation of the state institutions, they must find a way of making the state true to its normative function of providing the good life for its citizens. However, while the leaders were busy battling with this question, the people found the requisite avenues for meaningfulness in their ethnic enclaves.

In this essay, I will trace the problem of identity politics to the prevalence and nature of the ethnic question as a critique of the democratic legitimacy of most African states. The ethnic resurgence in postcolonial Africa, that is, speaks to the crucial need to build a democratic community that will tap into the demotic essence of the people as a significant factor in the legitimation crisis of the state. In this regard, I will analyse a recent attempt to answer the problem of community and democracy in Africa through the application of certain ideas intrinsic to liberalism. Within the framework of this essay, the pertinent question becomes: How viable is the attempt at fashioning an ñAfrican liberal democracyò? I will argue that while Rawls may be deployed to the African setting, his ideas would have to be modified substantially in a way not envisaged by those who advocate his relevance. It is only within the ambit of this revision that his idea of an overlapping consensus within the context of public reason becomes a viable means of confronting the problem of democratic legitimacy in postcolonial Africa. 


\section{The Lame Leviathan in the Postcolonial Realities}

It has become platitudinous to rehash the horror that attended the colonial situation. We will not do that here. However, suffice it to note that the confrontation of European colonialism with the African societies resulted into a multidimensional economic, political and socio-cultural crisis. Colonialism led to the ñindescribable crisisò and deep abject suffering of the Africans which consequently led to the irreversible disruption of their ways of life and the national psyche of the African societies. The impact of colonialism on Africa was, not surprisingly, out of proportion with its duration however long we conceive it. The major key that aids the understanding of the colonial situation was that the partitioning of the continent into colonial fiefdoms was simply motivated by the need to further the interests of the European powers. In this sense, Africa became a huge geopolitical chessboard and the partitioning a gigantic game played with real lands and real peoples.

The picture of the African nation-states that emerged from the emasculation of the African peoples and the amalgamating necessity that engulfed their societies, in Griffithsôwords, is that of ñiny statelets with minuscule economies and no political clout. $\hat{o}^{3}$ This turns out to be a very apt description in the light of the postcolonial crisis that attended decolonisation and the attempt of the African nationalists to assume the leadership of the debilitated economic, political and socio-cultural structures of Africa. It would seem obvious in the light of the above to say that Africa is really ñunderdeveloped.òWe can begin to untangle the colonial reasons for these postcolonial realities.

The first level of analysis speaks to the transmutation of the social question into the national question. In other words, the social question, simply put, was the question of how to raise the standard of living for the betterment of the 
people. In Urohô analysis, this was nothing more than a development issue. ${ }^{4}$ On the other hand, the national question involves the attempt to promote the artificiality of the state territories inherited from the colonialists to the detriment of the legitimate agitation of the masses for socio-economic meaningfulness. Clapham calls this the ñpolicy of state preservation.ò

To see the effect of this policy resulting from the transmutation of the social into the national question, we need to consider the second level of analysis. This simply involves the consequence of the uncritical acceptance of the colonial socio-political structure in its entirety by the national leadership. At independence, the African state structure lacks the requisite will to ñdeliver the goodsò promised by the nationalists. This was not surprising given the fact that the colonial state which the nationalists inherited was meant to operate with the underlying rationale of exploitation, oppression and subjugation rather than serve as an instrument of socio-economic transformation. This led to the profound contradiction between pre-independence expectations and post-independence realities. In time, it became clear to the leaders that to be able to maintain a firm grip on their inheritance, the logic of the colonial state must be maintained. To quote Clapham again, the policy of state preservation

é provides the raison d'être of governing elites and the base from which their power derives. The more successful they can establish their position as gatekeepersé the stronger is their brokerage position, the better are the bargains they can strike on one side or the other, and the greater the ñcommissionò they can extract in terms of personal benefits or freedom of political action. $^{5}$ 
These two levels of analysis led to the depoliticisation of the masses and the frustration of their expectations. This was achieved through the subconscious appropriation of the logic of the colonial state: the governed do not have to be willing or exercise any legitimising function; they only have to be controlled (if the leaders hope to keep their hold on power). ${ }^{6}$ The upshot of this is this. To prevent the collapse of the colonial spheres of influence which the African state structure represents, the leadership needed to promote the external requirement of unity by which we mean the policy of imposing a mechanical unity from above on the diverse, heterogeneous peoples and ethnic groups that have been arbitrarily restricted into artificial state jurisdiction. This external legal strength to mobilise coercive force around the artificial territories neglected what has been called the ñnormative condition of reconciliationò determined by an uncoerced, internal consent of the citizens.

In other words, the postcolonial state casts aspersion on the self-respect of groups and identities in its attempt to maintain an external territorial unity. The state assumes an amalgamating function driven by what Onesimo Silveira calls the ñmonistic power philosophy. ${ }^{7}$ It arrogates to itself the exclusive power to determine the national political space. In this sense, the ñnation-stateò expresses a legitimacy oriented on its legal-rational sovereignty, instead of that flowing from a demotic base. The paradox, however, is that within the context of a nation-state founded on national sovereignty we must also necessarily encounter the stateô commitment to the welfare of the people. Thus, instead of representing an icon of conjuncture, the hyphen between nation and state, for Appadurai, becomes a means of separation or an ñindex of disjunctureò: A sign of embattlement deriving from the stateô unsuccessful effort to exercise taxonomic control over difference. ${ }^{8}$ 
This postcolonial attitude of the state as an institution bearing rule over society forced on the African nationstate the character of the lame leviathan which has failed to contain and define significantly the lives of the people. The stateô pervasive and overbearing nature only succeeded in constructing the nation as an identity of resistance stigmatised by the centripetal logic. Put in another word, it cannot achieve what a commentator has aptly called the ñenpeoplementò of a political people, and has therefore become ña space devoid of normative meaningò which could only have grown out of the internal legitimising coherence which the people have transferred to their ethnic identity enclaves. What then is to be done? Or, as Menkiti put it, ñWhat is the basis of the peopleôs enpeoplement as a political people? ò $^{9}$

In the light of the issues raised in the preceding analysis, I believe it is safe to sum up the facts as follows. On the one side of the postcolonial divide we have the alienated people who, due to their material disenfranchisement, have taken to their ethnic communes in a bid to find normative meaningfulness. This also necessitated an act of ethnic self-definition and self-defence against the state. On the other side, we have the postcolonial state gripped in the logic of accentuating the external, legal-rational sovereignty to the detriment of its normative task of providing the good life. The confrontation of these two actors on the national political space is borne out by the famous analysis of the two publics in Africa by Peter Ekeh.

The unique character of African politics, according to him, derives from the normative weight that political actors ascribe to their participation in either public. That is, the dialectic of the two publics in African politics defines the zero-sum implication of the battle for political relevance and supremacy in the contested national space. To win an elec- 
tion, for instance, constitute the ultimate victory against the state and its various institutions. It is only obvious that the idea of an enabling political community and a democratic culture could never hope to emerge in such a context where the political actors are alienated from, and operate with a wrong perception of, the state. This is more so when the normative content of democratic legitimacy is ascribed to the primordial public rather than for the facilitation of the goal of national identity. Yet, Ekeh remarks that

Our problem may be partially understood and hopefully solved by the realization that the civic public and the primordial public are rivals, that in fact the civic public is starved of badly needed morality. Of course, ñmoralityò has an old-fashioned ring about it; but any politics without morality is destructive. And the destructive results of African politics in the post-colonial era owes something to the amorality of the civic public. ${ }^{10}$

What does morality require in the problem of governance in African political systems? Given the analysis of the postcolonial state and its amalgamating proclivity, one would no doubt see the sense in Menkitiôs suggestion that the specific goal of political analysis in this regard would be ñto be able to deny the state some of its claimed moral powers, such that individuals and communities can be left their freedom..$^{11}$ This is especially so in case of the postcolonial plural states in Africa in which several heterogeneous ethnic identities are mechanically forced into unity under the same political roof. To achieve this moral aim, one thing is significantly needed. This is that the state must be made to recognise the political force of the people it has assiduously been 
denying participation in the political system. That is, governance must return to its attempt to answer the social (i.e. development) question of increasing the living standard of the people.

\section{The Multinational Project: Rawlsian Considerations}

The pertinent question now is: What has liberalism got to do with all these? Menkiti gives us a preliminary reason. According to him,

Whether within or across cultures, there are now so many visions regarding what is the case, or what ought to be the case, that it often appears an impossible task to reconcile the various claims of individuals and of groups. It is my belief that although liberalism has traditionally been hailed as an ideal of freedom, of human liberation, it would be best, in these troubled times, to regard it as an efficient engine for the management of conflict, not as something to be defended because it promotes human freedom, whatever the moral content of the exercise of that freedom happens to be in actual practice. ${ }^{12}$

By liberalism, what Menkiti actually has in mind is the Rawlsian version of it. His choice of Rawls is commendable for three reasons. One, John Rawls, apart from Mill, serves as an example of a consummate liberal whose views sum up the details of liberalism. Two, and with specific reference to the ongoing liberal-communitarian debate, Rawls also serves as the reference point for the confluence of liberalism and communitarianism. In other words, in Rawlsôlater works, we find sufficient concessions to the communitarian critique 
to dismiss the charge that liberalism is basically individualistic. The third reason, alluded to in the above quote, is that Menkiti prefers to consider the political (i.e. procedural) rather than the comprehensive (i.e. substantive) Rawls.

To fully grasp the issues involved in the appropriation of Rawls, we need to adequately understand what the multinational project of the postcolonial state entails. What happened during the colonial period is that the colonialists tried, unsuccessfully, to create a multinational ñsociety of societies; Ò heterogeneous collection of several independent and semi-independent ethnic peoples into a straitjacket political arrangement with a system of law and a political order. This mechanical amalgamation failed because it involves constraining many nations into a restrictive national space meant in most cases for one national people. ${ }^{13}$ For the colonial enterprise, it was disadvantageous to give thought to the need to ñmould one citizenry from many peoples. ò The colonial laws and regulations became too inhibitive for the development of any sense of common belonging that could have made such multinational project work. As we noted earlier, the peoples do not need to be willing to legitimise the decision-making process. All that the colonial state demanded from them was their readiness to yield to colonial control. However, it became inevitable that the (post) colonial state should be starved of the much needed willing endorsement by the peoples as citizens.

While not paying lip service to the external legal sovereignty as a binding instrument in managing the affairs of a people, it should be significant to put into consideration the legitimising endorsement of the people in the attempt to achieve political consensus and articulate an arrangement that would ensure political enpeoplement. Onesimo argues in this wise that: 
This integration within a democratic system cannot happen without the consenting participation of the human element, which has to be integrated by means of a voluntary disintegrative process. The assignment of a marginal role to tribalism within the process of national integrationé should be considered with reservation, since it minimizes the role of the tribes and reduces the task of national integration to pre-conceived materialist schemasé The necessity of making the government politically viable thus became indistinguishable from the problem of constructing a shared set of values as a point of departure for using its institutional and constitutional toolsé What then makes the authority of the political leadership legitimate is thus not any substantive quality it inherently possesses, but a quality which is attributed to it by the members of the community. ${ }^{14}$

This task of finding an arrangement that will facilitate the convergence of the external legal rational requirement for statehood and the internal normative endorsement of the people is thus imperative if the postcolonial African nationstates hope to achieve the development of a political community and an accompanying democratic legitimacy. ${ }^{15}$

For Menkiti, this is where Rawls comes into the picture of the postcolonial realities in Africa. In a political situation of a zero-sum game which necessitates the violent conflict of mutually antagonistic ethnic actors, as Ekehôs analysis reveals, the proper strategy in this condition seems for Menkiti to be that of risk avoidance. In other words, if we are able to separate the parties in conflict on the basis of a mutually assured respect for the identity of the other, then we would have achieved much. Rawls is relevant because 
his theoretical baggage helps us to keep the parties from bringing their deep ethnic and cultural beliefs as to what is right or wrong to the political table. Reciprocity thus reinforces self-respect among the ethnic groups and minimises political violence. ${ }^{16}$ In Rawlsô view, when people and ethnic groups are allowed to bring what he calls their ñcomprehensive doctrinesò without qualifications into political deliberations, the result is almost always intractable political conflict and violence. However, rather than allow this, what is needed, for Rawls, is a ñreasonable overlapping consensus of comprehensive doctrinesò which engenders a conducive conception of political justice. Rawlsôrecent book, The Law of Peoples, is an attempt to theorise a standard set of principles that overlaps with the comprehensive doctrines of both the liberal and the non-liberal peoples.

However, for Menkiti, appropriating the Rawlsian theoretical baggage involves certain caveats. He is clear that the Rawls he finds germane to the African predicament is the procedural/methodological one (what he calls the Rawls of risk aversion) rather than the comprehensive one (or the Rawls of end-values). The comprehensive Rawls champions the need to extend the liberal world-view to non-liberal peoples as the only enduring and ñreasonableò panacea for freedom and human liberation. The political or procedural Rawls champions how the law of peoples can be constructed in a way that would not insist that the non-liberal peoples become liberal. For Menkiti, it is this political Rawls that facilitates the management of the political conflict in Africa without compromise.

Menkiti further disclaims the utility of the Rawlsian Original Position (hereafter, OP) as a strategy in the management of political conflict in Africa. Again, for him, freedom in the sense of an ultimate or end value which is crucial to Rawlsian liberalism must also be exchanged for a purely 
instrumental conception which allows a group or an individual the free articulation of their private beliefs. The worrisome alternative is that which gives people the perception that they have been subordinated to othersôview of what is valuable or right. Thus, within the context of these provisos, Menkiti seems optimistic that the African continent can expect the emergence of an era of representative government once the state recognises its normative function vis-à-vis the citizens, and the peoples also recognise the significance of deferring to the reasonable principles of the law of peoples which overlap with the comprehensive doctrines of others.

In my opinion, two questions are necessary before we can begin to comprehend the relevance of Rawls: One, how relevant are these Rawlsian considerations for Africa? Two, to what extents can the political Rawls be distinguished from the comprehensive one? I will attempt to use the second question as a means of answering the first.

In The Law of Peoples, Rawls argues that the law of peoples can reasonably be developed out of liberal ideas of justice and extended to non-liberal peoples in such a way that would not require them to be liberal. If this strategy is properly carried out, for Rawls, it ought to yield a set of principles of justice that will be applicable to all democratic and decent peoples, liberal and non-liberal alike. These principles of justice are:

(1) Peoples are free and independent and their freedom and independence are to be respected by other peoples;

(2) Peoples are equal and parties to their own agreement;

(3) Peoples have the right of self-defence but no right to war;

(4) Peoples are to observe a duty of nonintervention;

(5) Peoples are to observe treaties and undertakings;

(6) Peoples are to observe certain specified restrictions on the conduct of war; 
(7) Peoples are to honour human rights;

(8) Peoples have a duty to assist other peoples living under unfavorable conditions that prevent their having a just or decent political and social regime. ${ }^{17}$

The first grave suspicion raised by Rawlsô strategy in The Law of Peoples derives from the attempt to extrapolate the fundamental principles of political liberalism to a global scale. My contention is that the ñreasonableò in the idea of overlapping consensus is really the liberal in spite of Rawlsô protestation to the contrary. In other words, Rawls only uses a covert attempt to prove, one, that the liberal social contract is universal in its reach; and, two, that the structure of the law of peoples is inherently synonymous with the liberal conception of justice.

Rawlsôstrategy of extrapolation derives from his constructivism. This view conceives of general liberal ideas as erected ñby way of a reasonable procedure in which rational parties adopt principles of justice for each kind of subject as it arises..$^{18}$ The process starts with the basic political structure of a ñclosed and self-contained democratic societyò and is then pressed outward to embrace principles for the law of peoples. Rawls comments that:

é it is characteristic of a constructivist idea of justice to regard the distinctive nature and purpose of the elements of society, and of the society of peoples, as requiring persons, within a domain where other principles leave them free, to act from principles designed to fit their peculiar roles. As we shall see as we work out the law of peoples, these principles are identified in each case by rational agents fairly, or reasonably, situated given the case at hand. ${ }^{19}$ 
Given the premise of constructivism therefore, Rawls will extend the liberal principles of justice to what he calls the ñhierarchicalò societies. On Menkitiôs own admission, he contends that his aim in considering a Rawlsian perspective in respect of the postcolonial African state is not to insist that African states can be regarded as ñmembers of the European or Western families of liberal democracies. ÒThis is because the differences in the two types of societies are too obvious to sustain such a claim. ${ }^{20}$

However, the word hierarchical is a blanket term that differentiates between ñdecentò and ñburdenedò societies. A well-ordered decent society, for Rawls, is one that is not expansionist, that possesses political institutions which constitute ña reasonable consultation hierarchyònecessary for representative purposes, and that respects basic human rights. A burdened society, on its own, is an outlawed or criminal society that flouts all these requirements. The question now is to ask how different or hierarchical African societies are. We will come to this soon.

Rawls is then faced with the challenge of explaining how we start with one constitutional democracy and turn that into a society of liberal and ñdecentò countries that would eventually encompass a universal society of peoples operating on the same basic principles of justice. This is especially serious when we note that such a significant experiment is not meant to include the ñcriminalò societies. Rawlsôexplicit appropriation of the framework of the OP reinforces our earlier suspicion. The OP is crucial to the constitution of the conception of justice in liberal societies and must therefore also be critical in the attempt to extend that conception to hierarchical societies. It is rather unfortunate that in spite of his explicit rejection of the OP as a suitable framework for the African context, Menkiti fails to understand how intrinsic the OP is to the formulation of the supposed law of peoples. 
We can now begin to speak to our earlier questions. The first point is to determine where African societies should be placed in the distinction between the decent and the burdened societies. I suspect that in liberal reckoning most societies in the third world are burdened. The usefulness of these concepts is however limited because they do not actually help us to untangle the problem of how to differentiate the decent from the burdened. For instance, there is always an element of one or the other characteristic of decency or criminality in the liberal (hence, decent) and the illiberal (hence, burdened) societies. It is doubtful for instance that the United States respects human rights especially in her relation with the peoples of those states in which she intervened. Nigeria, on the other hand, in spite of her not so impeccable human rights record, still possesses a semblance of representative institutions.

If it is correct, however, to see African countries as basically burdened, then Menkitiôs Rawlsian considerations become suspect. And even if the characterisation is not correct, the framework of the OP still diminishes its usefulness in the African context. For instance, according to Green, the $\mathrm{OP}$ is an odd strategy because it does not speak to the problem of international distribution of wealth for example. That is, Rawls supposes that the parties to the international original position would care only about the maintenance of the internal justice of their societies and not about whether they are wealthy or poor. However, Green argues, even if one grants the point that the primary aim of a society is to be just, ñit does not follow that any actual societies are indifferent between wealth and poverty; being wealthy isnô the primary thing thatố valuable, but itôs still valuable. ${ }^{21}$ Thus, one could on the basis of this question how relevant the OP would be to the postcolonial need for a just society and also for socio-economic transformation. 
To drive home this point, consider the conception of ñpublic reasonò which motivates the political Rawls and the idea of overlapping consensus. By public reason Rawls means the body of generally accepted common sense beliefs and ways of reasoning, as well as uncontroversial scientific conclusions; that is, ñ the reason of the public.ò It specifies, for instance, certain ñbasic rights, liberties and opportunities, assigns them priority and affirms measures assuring citizens the means to make effective use of them. $0^{22}$ It seems to me that this conception of the public reason significantly disrupts the utility of the OP in the formulation of the law of peoples. This is because it seems difficult, under the definition, to exclude the comprehensive beliefs of a people from participating in the public reason. In other words, a public reason in which liberal and non-liberal peoples are supposed to participate would be meaningless without the peculiar cultural or socio-political background of the participating countries. This is how Fagelson puts the same point:

Both liberals and conservatives can sincerely believe that they are engaging in public reason without there being any area of consensus. The only way to obviate that outcome is to abandon any pretense of neutrality and ground public reason in the comprehensive liberal ideal of moral pluralism. Rawls goes part way toward this solution but does not appear to regard his definition of public reason as a comprehensive liberal principle but rather simply a reasonable political principle given a morally plural world. How can we require that people to be governed even in the political sphere by this notion of reason unless they believe that this is the correct understanding of it? Moreover, why would anyone believe that this was the correct standard of reason unless they already believed in some comprehensive doctrine rooted in Locke, Kant or Mill? ${ }^{23}$ 
The tenuous boundary between engaging in the construction of public reason and the attempt to foist the liberal comprehensive doctrines on the non-liberal others inevitably breaks down. Rawls is therefore essentially comprehensive, and the ñreasonableò becomes essentially the liberal. In other words, if Menkitiôs assertion is correct that African countries do not possess membership of the families of liberal democracies, Rawls becomes a bad choice in the attempt to analyse the problem of democratic community and legitimacy in the African context.

How do we then move from this point to the resolution of the African crisis; that is the requirement for the enpeoplement of a political people?

\section{Towards an Integrative Culture of Governance}

The objective of this essay is to question the theoretical ability of liberalism, as a paradigmatic ideology of the modern state, to achieve a sustainable social unity in plural states without at the same time ensuring the perpetual domination and marginalisation of vulnerable ethnic groups and identities.

In the African context, it implies asking whether the liberal theoretical framework can fashion an adequate conception of democratic legitimacy that will enable the postcolonial state achieve a viable (multi)national unity. We have been arguing so far that liberalism, given its supposed neutrality, cannot enable the state mediate among the volatile identity groups in a plural society. This is because liberalism is irreparably comprehensive and thus must often take its own side in the public sphere. Menkiti therefore ought to have taken serious his own advice that before Rawls can be deployed in an African setting, ñthe ongoing debate between contract theory and communitarianism needs to be addressed. $0^{24}$ 
In order to be able to achieve a ñfruitful engagementò between the liberal philosophy and the communitarian culture in Africa, Rawlsôsupposed concession to communitarianism must be adequately scrutinised. We will proceed to do this via another look at the proposed law of peoples. This law, we should note, need not be subsumed under the liberal conception of justice as Rawls would have us believe. As Menkiti himself recognises, it flows from standard assumptions about the relation among peoples with different comprehensive beliefs. I agree with Menkiti that the first principleð that peoples are free and independent, and their freedom and independence are to be respected by other peoplesठ is the most significant and far reaching and from which others can be derived. It is significant in this context because it accords with the goal of resolving the African predicament: the peaceful coexistence of ethnicities and social identities in the political community on the basis of reciprocal self-respect and self-worth.

Rawlsôconfrontation with this first principle falls far too short of this goal. The unifying strategy of toleration which underlies his perspective in The Law of Peoples is a beautiful strategy until it is applied to a context defined by the concurrence of difference with identity. The African political context with its zero-sum, non-egalitarian, ñmajority norms and minority defianceòattitude belies the politics of toleration favoured by liberals. Toleration is deficient I suspect because the liberals fail to adequately conceive the nature of culture. In liberalism, culture is characterised as an aspect of ñcollective goodsò, the goods that we share in common. In this sense, it becomes a model of aggregate goods which are ultimately reducible to individual goods. Yet culture is a collective good that is not so reducible. It is rather a universal value available to everyone, a pre-condition for treating people with equal respect. ${ }^{25}$ 
This appears to be the whole point of Menkitiô appropriation of the political Rawls and his framework of public reason. However, as we have argued, the configuration of this public reason must be on the basis of the recognition of equal worth of the participating cultures rather than the homogenising structure necessitated by ideal theory. I will follow Charles Taylorôs conception of the significance and role of culture in the consolidation of the identity of a given people. There seems to be much to agree with in Taylorôs thesis that

é our identity is partly shaped by recognition or its absence, often by the misrecognition of others, and so a person or group of people can suffer real damage, real distortion, if the people or society around them mirror back to them a confining or demeaning or contemptible picture of themselves. ${ }^{26}$

The sense of the damage is deepened given the fact that the denigrated culture has served as the mode of the people $\hat{Q}$ perception of the good, the sacred and the beautiful for a long period of time; that is, their ñhorizon of meaningò. For Taylor, recognising a culture in this sense is critically tied in with their identity as a people. That is, culture provides a crucial moral sense to the idea of being $m e$; the original way of expressing my humanity.

It is this nature of the human condition that encapsulates the connection between identity and recognition. For Taylor however, a monological view of the moral sense distorts the character of the human life which is fundamentally dialogical. He contends that ñWe become full human agents, capable of understanding ourselves, and hence of defining our identity, through our acquisition of rich human languages of expression..$^{27}$ Language in this sense denotes cul- 
ture because it goes beyond the words we speak to encompass the expressions that define us: the ñlanguageò of art, of gesture, of love, of morals, of the holy, and so on. In other words, the definition of who we are, is not restricted to a monological conversation with an inner moral sense, it is sharpened by an ongoing dialogue with ñsignificant othersò with whom the story of our beings are tied. If, as Taylor argues, identity means ñwhere we are coming from, ò then it becomes difficult to reject the point that a background of crisscrossing, cultural narratives is essential. ${ }^{28}$ It therefore becomes clear how my identity can be damaged by the recognition or misrecognition of the significant others.

Political flourishing is only possible to the extent that an identity is recognized in the national space. To lose out implies not only that one becomes politically unrecognised and thus insignificant in the political scheme of things, but also that such an identity faces the imminent danger of cultural mortality. Furthermore, for Taylor, there is a kind of mutual depreciation that is tied to the strategy of one culture depriving another of the needed recognition of its self-worth and respect. According to him, while it is true that misrecognition damages the unrecognized, those who deny this recognition to others are also subtly frustrated ñbecause they win recognition from the losers, whose acknowledgment is, by hypothesis, not really valuable, since they are no longer free, self-supporting subjects on the same level with the winners. $0^{29}$ The struggle for recognition can find only one satisfactory solution, and that is a regime of reciprocal recognition among equals.

A politics of recognition therefore addresses the principle of equal dignity and self-worth. A cultural category which provides a locus for the development of oneô identity is not only worthy of cultural survival, it also ought to be respected (and not just tolerated) by everyone. When a peo- 
pleâs culture is forced into a homogenising mould that insists on its being tolerated, the identity of such a people becomes inauthentic and devoid of a moral sense.

It is not difficult to see the manifestation of this analysis in the context of the politics of postcolonial Africa. The nature of this politics derives, as we have argued, from the perception of the postcolonial state as a prized category which a culture has a moral permission to defraud at any point of its confrontation with its structures. This perception leads to a zero-sum political game with enormous implication for the identity of the ethnic participants in the game. In the competition for the ultimate control of the state and scarce resources, an ethnic group that loses out, loses in two crucial senses: they not only fail to participate in the appropriation of scarce resources, but they also lose their inherent dignity and self-worth and the significant respect that flows from it. In fact, such a culture faces an almost irreparable obscurity in the national space. Thus, the inability of the postcolonial state in Africa to harness the loyalty of its warring ethnic constituents is due, inter alia, to the conviction of these identities that the others are not ready to give their comprehensive beliefs about what is the case its rightful place in the reasonable scheme of things.

The import of Taylorô politics of reciprocal recognition in the resolution of this intractable problem of governance is that it affirms the necessity in a political community of a regime of common purpose which flows from the mutual self-respect which the recognition of the dignity of a cultural identity brings. This necessity of a common political purpose is what Abraham has in mind when he writes about an ñintegrative cultureò within the African context.

An integrative conception of culture, for Abraham, provides the basis for the idea of culture as a universal precondition for non-discrimination and for equal and reciprocal 
self-worth and self-respect in the public sphere, and the genesis for the being of a nation. This means that once the ethnic identities are assured of the recognition of their mode of being by others, it becomes possible for them to channel their hostile posture to the success of a national political unity. Abraham comments:

The point of a culture which I have been dwelling on is that it is the source of solidarity, of the complex mechanism, symbols, and ideologies of social integration and common belonginess; if you like, the living being of a nation. Nation-building requires that more parochial allegiances like tribal ones should not take up a strong and hostile posture. ${ }^{30}$

One is likely to accept the point of the argument that ethnic conflicts have been motivated by the lack of recognition of the worth of what makes up the identity of the group. And that once this is done, that is, once culture has been put in its place as the basis of national involvement, then national problems and events become absolutely intelligible through the prism of shared discourse. This is so because since national issues arise within the context of the national situation, they also derive their significance from the shared ideas, attitudes and techniques which the people ñunderstand and with which they are able to cope, and have lived. ${ }^{31}$ Furthermore, the common acceptation of national events makes it possible for the people to accept the policy implications of the events and to give then a ñchance of authenticity.ò It is crucial therefore to recognise that the authenticity of a cultural identity is proportional to the authenticity of a national identity crucial to the legitimacy of the postcolonial nation-state in Africa. 
A significantly self-authenticating culture provides an integrative possibility which is absent in a rightsphilosophy. In this sense, it is not difficult to see the point of the idea that to resolve the postcolonial problem of governance, we need a strategy that will prevent these groups from bringing their comprehensive beliefs to the political table. This can only happen when these identities are convinced of the sincerity of the other participants to recognise their substantive presence at such a table. This is the significance of the political Rawls buried under the parochial preoccupation with the liberal. However, as we have shown, rightsliberalism espoused by Rawls will inherently run contrary to the politics of recognition. One reason is because the recognition of collective goals runs contrary to the principle of individual autonomy defined by a set of individual rights which insist on an equal treatment of citizens irrespective of their colour or culture. By this very fact, rights-liberalism reveals its inadequacies as a theory that can deal with the desire for cultural survival and self-worth which is behind the agitation for recognition. The other reason is that the $\mathrm{OP}$ is simply a camouflage for the cultural expression of the liberal culture which consequently insists on the homogenisation of ñthe Others.ò

If this is correct, then the idea of public reason and an overlapping consensus proposed by the political Rawls becomes a worthwhile theoretical framework which must nevertheless be significantly modified if it is to be relevant in the resolution of the problem of African governance. The ideal theory which the OP presupposes lacks a historical dimension because it casts the situated experiences of real people into a theoretical device and transforms it into a hypothetical situation. The suggested modification is the conception of a different ñiberalò organisation of the society that would be suitable for the postcolonial context of Africa and would suitably address the problem of democratic legitimacy 
which derives from the mutually recognised worth of the ethnic constituents in the discourse of national identity. This is the modification we have been analysing.

Unlike the Rawlsian rights-liberalism which is supposedly procedural but is really substantive in the sense that it advocates a homogenising unity irrespective of the aspirations of the suppressed cultures, this alternative liberal conception organises society ñaround a definition of the good life, without this being seen as a depreciation of those who do not personally share this definition..$^{32}$ This liberalism would be capable of respecting diversity because it would have as its focus the crucial issue of cultural survival which the comprehensive Rawls cannot allow. In this sense, the procedural Rawls and the principle of overlapping consensus deriving from public reason becomes a crucial framework for the alternative conception of liberalism. In this public reason suffused with the recognition principle, it seems reasonable that the ethnic identities could be persuaded to distance their comprehensive doctrines from the national discourse. This is the whole point of Menkitiôs appropriation of Rawls.

We are led from here to consider the institutional prerequisites necessary for the sustenance of a politics of equal and reciprocal self-respect and recognition. If cultures are as important as we have tried to portray them, it becomes necessary that cultural communities whose identities are tied in with the legitimate identity of the nation-state ought to be protected from the hand of the overbearing state operating on the logic of external sovereignty and aggravated centrality. This should be the case if we grant that individuals as peoples are generic proxy for communities. The assumption underlying this essay has been that if the nation-state fails to recognise this proximal connection between peoples and communities, it would perpetually be searching for legiti- 
macy. This is what we can call the democratic link between the idea of recognition and the nature of the state. Two institutional features can firmly put the state on the way to being a demotic structure.

The first way to facilitate the legitimation of the state is to impress on it the burden of democracy. This burden is the stateô responsibility for, and responsiveness to, the interests of those that give it a legitimising meaning. Thus, in this sense, a formal representation of identities (what has been called the politics of ideas ${ }^{33}$ implicit in the strategy of toleration) could only truncate the significant experience of those whose ideas are being represented. The point however is to compliment a formal representation with a large, enabling dose of substantive representation (or the politics of presence implicit in the strategy of recognition). This means that the idea represented is as important as those who are representing it; if the idea supersedes the presence, there is the ever present danger of re-presentation which is inimical to the democratic process. Furthermore, the coincidence of formal and substantive representation challenges the orthodox structure of the state as an amalgamating institution with the coercive monopoly to structure the national space to the exclusion of its constituents.

The second way to force the hand of the state is to insist on its managerial responsibility. This task is primarily that of making the state an agent of the good life for the people. One may therefore conclude with Menkitiôs optimism that

é if the African state succeeds in maintaining security, providing infrastructure, and facilitating trade, if it could understand itself as being an agent, in good faith, for these three things, then its functions would have been well served. Citizens can vote their will on these matters, 
and when they do, and their leaders respect the outcomes of their votes, then an era of representative democracy would have arrived on the continent. $^{34}$

I believe this is the only sense in which we can reasonably talk of ñiberalò societies in Africa or of the significance of Rawls in the African predicament.

\section{Notes and References}

1. William Abraham, The Mind of Africa (London: Weidenfeld and Nicholson, 1962), p. 27.

2. Ifeanyi Menkiti, ñPhilosophy and the State in Africa:

Some Rawlsian Considerations, ò Philosophia Africana, Vol. 5, No. 2, August 2002, p. 42.

3. Ienan Griffiths, The African Inheritance (London:

Routledge, 1995), p. 7.

4. Chris Uroh, ñIntroduction: Situating the Challenge of Development in AfricaòUroh (ed.) Africa and the Challenge of Development: Essays by Samir Amin (Ibadan: Hope Publications, 1998), pp. 2, 3.

5. Christopher Clapham, Third World Politics: An Introduction (Wisconsin: University of Wisconsin Press, 1985), p. 114.

6. Ifeanyi Menkiti, ñPhilosophy and the State in Africa,òp. 42. 
7. Onesimo Silveira, Africa South of the Sahara: Party Systems and Ideologies of Socialism (Uppsala: Publications of the Political Science Association, 1976), chapter 5.

8. Arjun Appadurai, Modernity at Large: The Cultural Dimension of Globalization (Minneapolis: The University of Minnesota Press, 2000), p. 189.

9. Ifeanyi Menkiti, ñPhilosophy and the State in Africaé òp. 37.

10. Peter Ekeh, ñColonialism and the Two Publics in Africa: A Theoretical Statement,ò Comparative Studies in Society and History, Vol. 17, No. 1, January 1975, p. 108.

11. Ifeanyi Menkiti, ñPhilosophy and the State in Africaé ò p. 46.

12. Ibid. p. 37.

13. Ibid. p. 41.

14. Onesimo Silveira, Africa South of the Sahara, pp. 56, 77.

15. Olusegun Oladipo, ñModernisation and the Search for Community in Africa,òin Olusegun Oladipo (ed.) Remaking Africa: Challenges of the Twenty-First Century (Ibadan: Hope Publications, 1998), p. 115.

16. Ifeanyi Menkiti, ñPhilosophy and the State in Africaé ò p. 39 . 
17. John Rawls, ñThe Law of Peoples, ò The Amnesty Lectures http://www.usm.maine.edu/ bcj/issues/three/ rawles.html See also Rawls, The Laws of Peoples (Cambridge, Mass.: Harvard University Press, 2001), p. 37.

18. Rawls, ñThe Law of Peoples, òp. 2. The Rawlsian strategy conceals the critical assumption that liberalism provides an uncontestable background for the law of peoples.

19. Ibid. p. 3.

20. Ifeanyi Menkiti, ñPhilosophy and the State in Africaé ò p. 38 .

21. Michael Green, ñRawlsô Law of Peoples, ò Human Rights I (Fall 2000) http://humanities.uchicago.edu/faculty/ mgreen/HumanRtsFoo/Notes/class/KRawls.html

22. Cynthia B. Cohen, ñReligious Belief, Politics, and Public Bioethics: A Challenge to Political Liberalism, ò Second Opinion, No. 6, May, 2001 http://www.parkridgecenter.org/ Page509.html

23. David Fagelson, ñTwo Concepts of Sovereignty: From Westphalia to The Law of Peoples?ò International Politics, Vol. 38, No. 4 (December 2001), http:// academic2.american.edu/ dfage/ TwoConceptofSovereignty.htm Emphasis added. Fagelson adds that liberalism cannot be neutral about itself. ñAt some point liberalism must be willing to take its own side in the argument and assert that this is the most just way to live given the constraints of human nature as it understands it.ò 
24. Ifeanyi Menkiti, ñPhilosophy and the State in Africaé ò p. 47.

25. In Multiculturalism, Charles Taylor argues that culture is a universal condition which shapes every personality and is indispensable for social life. For him,

é it is reasonable to suppose that cultures that have provided the horizon of meaning for large numbers of human beings, of diverse characters and temperaments, over a long period of timed that have, in other words, articulated their sense of the good, the holy, the admirableð are almost certain to have something that deserves our admiration and respect, even if it is accompanied by much that we have to abhor and reject.

26. Charles Taylor, Multiculturalism: Examining the Politics of Recognition, edited and introduced by Amy Gutmann (New Jersey: Princeton University Press, 1994), p. 72.

27. Ibid. p. 25.

28. Ibid. p. 32.

29. Ibid. p. 33.

30. William Abraham, The Mind of Africa, p. 27.

31. Ibid. p. 39. 
32. Charles Taylor, Multiculturalism, p. 59.

33. Cf. George Carew, ñDevelopmental Democracy and Postcolonial Politics, Ò Quest, Vol. X, No. 2, December 1996, p. 12.

34. Ifeanyi Menkiti, ñPhilosophy and the State in Africaé ò p. 38. 